Trivium: Estudos Interdisciplinares, Ano XIII, Ed. 2. p. 1-2.

http://dx.doi.org/10.18379/2176-4891.2021v2p.1

\title{
Editorial
}

\section{Passages, Losses and Pandemic}

Closing the 2021 editions of Trivium: interdisciplinary studies, this last issue is composed of a series of thematic articles divided into three axes - Passages, Losses and Pandemic, centered in the psychoanalytic concept of mourning. The vast majority of these essays present large clinical research and discussions about different mourning processes.

In the first article, "The place attributed to parents in the suffering of adolescents", Rita Hentz and Daniel Kupermann investigate, through a qualitative research, what role the subject, in the transition to adulthood, attributes to the parental figures in his psychic suffering. The article "The unbearable female enigma in a case of self-injury in adolescence", by Rebeca E. Cruz Amaral and Luciana G. Coutinho, is a construction elaborated from the case study of an adolescent who harmed herself, her relationship with her mother and the enigma of the feminine. In the second axis, Eduardo Brandão, in "A psychoanalytic approach of the family couple in a legal dispute around the child", brings a forceful discussion about the care of families in litigation, whose dialectics of desire and enjoyment provide the clues for the union and disunion of the couple that gave rise to the child. Finally, in the third axis, Camila B. Rangel and José Maurício Loures, in "For an erotic of the end: mourning in the context of the COVID-19 pandemic", based on certain clinical managements of the mourning process introduced by Jacques Lacan and Jean Alouch, propose new modes of intervention in mourning in the context of hospital clinical practice, considering the recent experience of one of the authors with the Virtual Family Visits (VVF's) at the Macaé Public Hospital- HPM/HPMIH. "Ferenczi and the catastrophe: breaking the boundaries" of Leonardo Câmara and Regina Herzog" brings a forceful reflection on the COVID-19 pandemic, based on the concept of catastrophe as formulated by the Hungarian psychoanalyst Sándor Ferenczi.

In the free articles section, Noga Wine, in "The variable session", offers the reader a study on the origins of the handling of time in psychoanalytic practice elaborated by Jacques Lacan. "Sándor Ferenczi and Melanie Klein: the psychoanalysis of the analyst as the foundation of training", by Alexandre Patrício de Almeida and Alfredo Naffah Neto, 
highlights the fundamental importance of the analyst's analysis as the crucial point of his own training, based on some considerations by Freud and on the enriching contributions by Sándor Ferenczi and Melanie Klein on this subject. Closing the free section, “Transvestism and femininity”, by Christiana P. de Oliveira and Manoel Tosta Berlinck, is a clinical essay. The encounter between the clinician and patient is discussed from the perspective of fundamental psychopathology.

We chose to publish, in this issue, in which situations of loss are addressed, the lecture by Argentine psychoanalyst Ana Petros "My name is "nobody' and "nobody" they call me. The undifferentiated". The author invites you to reflect on the infinite mourning involved in migration, as the object of mourning, the country of origin does not disappear allowing the fantasy of return to be kept alive.

Finally, the review "What do the dead have to tell us?", by Cintia Lobato, and the essay "The work of mourning in the series Fleabag, by Phoebe Waller-Bridg", written by Arthur T. Pereira and published in the Arts section, end with a flourish the thematic proposal of the edition.

Betty Bernardo Fuks

Editora Responsável 